\title{
Is hidrorium able to improve the students' critical thinking skills?
}

\author{
Dedy Dwi Setyawan, Ali Mustadi \\ Department of Primary Education, Pascasarjana, Universitas Negeri Yogyakarta. \\ Jalan Colombo No. 1, Yogyakarta 55281, Indonesia \\ * Corresponding Author. Email: dedydwi.2018@student.uny.ac.id
}

Received: 19 December 2019; Revised: 15 February 2020; Accepted: 3 April 2020

\begin{abstract}
The condition of the students' critical thinking skills in the Kowangbinangun State Elementary School has impacted their learning results. Departing from this situation, a study for improving the students' critical thinking skills and learning results by using hidrorium as the media should be conducted. Within the conduct of the study, the approach that had been adopted was the classroom action research. Then, the instruments that had been implemented were the test instrument, namely the test items for measuring the achievement of the students' learning results, and the non-test instrument, namely the assignment assessment rubric for measuring the students' critical thinking skills level. Furthermore, the data analysis method that had been adopted was the descriptive-comparative method. Within the first cycle, $4 \%$ of the students belonged to the "Very High" category, $14 \%$ of the students belonged to the "High" category, and $82 \%$ of the students belonged to the "Low" category; as a result, $33 \%$ of the students met the passing grade while $67 \%$ of the students did not meet the passing grade. The research in the first cycle improved the students' critical thinking skills and thus $14 \%$ of the students belonged to the "Very High" category, $57 \%$ of the students belonged to the "High" category, and $29 \%$ of the students belonged to the "Low" category. Following up the improvement, the learning results of the students showed that $64 \%$ of the students met the passing grade whereas $36 \%$ of the students did not meet the passing grade. In the second cycle, the students' critical thinking skills also improved since $86 \%$ of the students belonged to the "Very High" category and $14 \%$ of the students belonged to the "High" category. Thus, the students' learning results improved as well with $82 \%$ of the students met the passing grade and $18 \%$ of the students did not meet the passing grade.
\end{abstract}

Keyword: Hidrorium, Critical Thinking Skills, Learning Results

How to Cite: Setyawan, D., \& Mustadi, A. (2020). Hidrorium: Improve students critical thinking skills at primary school?. Jurnal Prima Edukasia, 8(1), 20-28. doi:https://doi.org/10.21831/jpe.v8i1.28946

\section{Introduction}

In the learning process of the $21^{\text {st }}$ Century, students are expected to master four skills that consists of: (1) creativity and innovation; (2) critical thinking and problem-solving; (3) communication; and (4) collaboration. These skills are necessary for the students to master so that the students might compete one another in order to improve their skills within the domains of well-qualified education. In response to the statement, the 2013 Curriculum serves as an effort from the government in improving the learning quality within the $21^{\text {st }}$ Century. The reason is that within the learning process of 2013 Curriculum a theme serves as the means for integrating the contents of several lessons within the Elementary School degree. By integrating these contents under a single theme, it is expected that the theme might be a single entity and an association with the students' experiences in the daily life so that the learning process will be more meaningful (Mulyasa, 2014). However, a meaningful learning will only be achieved when the students are able to uncover information and solve problems. Therefore, there should be certain skills that might support such ability. With regards to the statement, critical thinking skills refers to the higher order thinking skills that enable the students to perform analysis by viewing the existing facts, proposing arguments, and displaying courage to draw conclusions properly (Adnyana, 2012, p. 202). Through the critical thinking skills, the students are able to make decisions by using logical, reflective, and productive consideration (Desmita, 2012). 
Jurnal Prima Edukasia, 8 (1), 2020 - 21

Dedy Dwi Setyawan, Ali Mustadi

In order to stimulate the students' critical thinking skills, several media might be utilized since the success of a learning process is inseparable from the role of the media. Not to mention, media is an integral part of the educational process within the school (Y. W. Astuti \& Mustadi, 2014). According to Vikagustanti et al. (2014, p. 469), the use of learning aid or learning media is inseparable from the learning method that has been adopted. In other words, media play an important role within the learning process because media serve as the means for transmitting messages in the form of the learning materials that a teacher delivers so tha the students might receive the lessons that have been delivered. Thus, the appropriate use of learning media is important within the learning process since media possess several advantages and one of these advantages is that media are able to put abstract and complex concepts into real, simple, systematic, and clear objects.

Mustadi et al. (2018, p. 9) suggests that in order to create meaningful learning a teacher should be smart in coordinating the classroom by using various methods and media and also by paying attention to the targeted environment, condition, and objective; by doing so, an enjoyable learning might be created. In line with the explanation, Falahudin (2014) states that the forms of the interaction between the learners and the learning sources might be various and one of these forms is lecture. Unfortunately, lecture will be less effective if it is implemented in the elementary school students. Therefore, there should be additional media that serve as a backup in transferring what the teachers have been teaching. Then, the use of media within the learning process displays several advantages as follows: (1) developing the students' learning motivation; (2) providing clearer meaning on the materials that have been studied; (3) eliciting variety within the learning method; and (4) assigning more learning activities to the students (Nurseto, 2012). Departing from these benefits, one of such media will be implemented and the intended medium is the one that utilizes the fish cultivation known as aquaponic. According to (Santoso \& Arfianto, 2014), as having been supported by the argument from Putra et al. (2013) and also by the argument from Hadi (2016, p. 134), aquaponic has been designed as one of the efforts for overcoming the water pollution due to the fish cultivating activities and, at the same time, has also become an alternative for reducing the water in the fish cultivating activities. Due to the relevance between the aquaponic and the materials that the students will study, the aquaponic will be utilized as a learning media under the title Hidrorium. The term hidrorium is actually an acronym of two terms namely hidroponic and aquarium or fish tank. The name hidrorium has been selected this media is the simple version of aquaponics, which might be used within the learning process in the classroom.

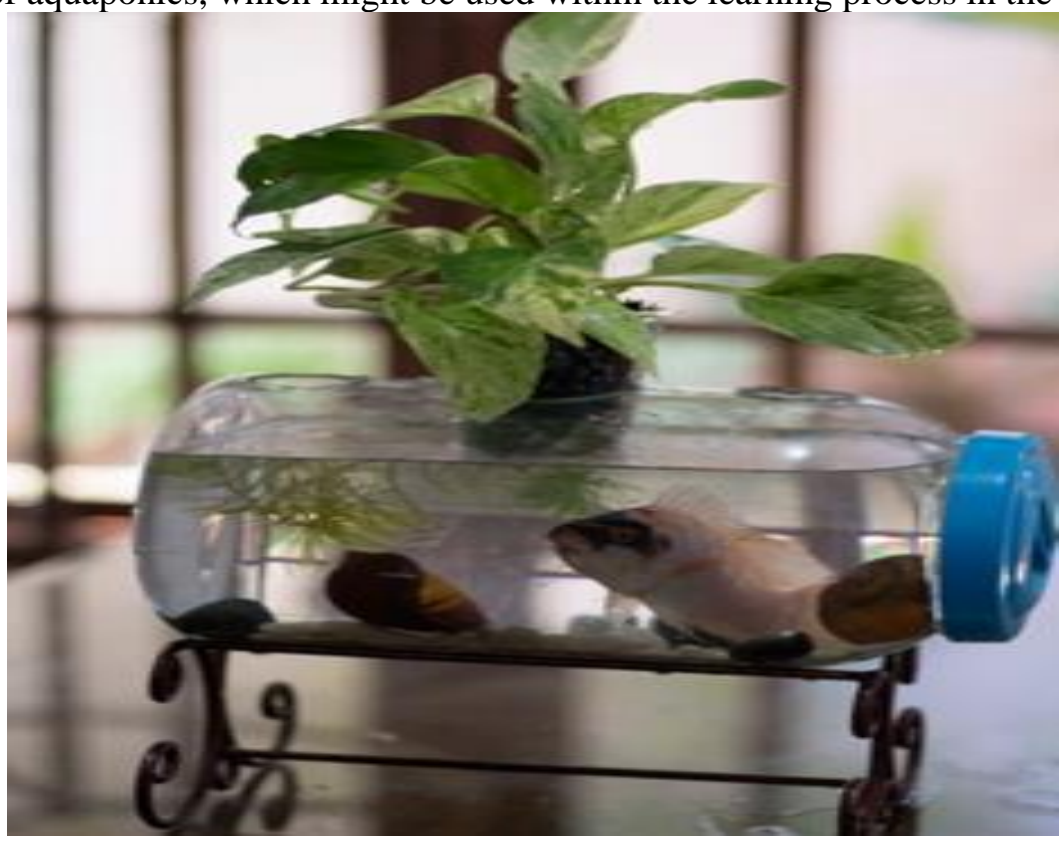

Figure 1. Example of Hidrorium as Learning Media

Based on the results of the observation and the interview in the Kowangbinangun State Elementary School, it is found that the teachers have tried to implement the learning process that stimulates the students to take active role in the learning by using stimulants in the form fo reading texts and pictures. Unfortunately, this effort has not returned in great encouragement for the studens to be 
Jurnal Prima Edukasia, 8 (1), 2020 - 22

Dedy Dwi Setyawan, Ali Mustadi

active in the learning process. According to the teachers, the students tend to be passive within the learning process as having been marked by the fact that the students are unwilling to raise question unless they are appointed by the teachers. This situation certainly indicates the low level of the students' critical thinking skills since $4 \%$ of the students belong to the "Very High" category, $14 \%$ of the students belong to the "High" category, and $82 \%$ of the students belong to the "Low" category. These findings have direct impact toward the students especially the Grade V students of the Kowangbinangun State Elementary School. In this regard, 70 has been the minimum passing grade for the contents of Natural History. Despite the minimum passing grade, $33 \%$ of the students have met the minimum passing grade while $67 \%$ of the students have not. Looking at these findings, it is expected that the utilization of hidrorium might serve as a solution for improving the students' critical thinking skills and learning results. Being simple and easy to assemble, this medium might provide meaningful learning for the students in the activities of observing, analysing and drawing conclusions for the contents of Natural History on the artificial ecosystem and mutual dependency among living organisms.

\section{Method}

The nature of the study was Classroom Action Research (CAR). The nature had been adopted in order to define the efforts that should be pursued in improving the learning quality and the teacher responsibility in managing the learning process (Sanjaya, 2008). On the other hand, the design that had been adopted for the conduct of the study was the Kemmis et al. (2014) model. The spiral shape of the Kemmis \& McTaggart Model consists of three steps in each cycle namely: (1) planning; (2) action and observation; and (3) reflection (Kemmis et al., 2014). Within the conduct of the study, the number of the cycle that should be completed was adjusted to the results of each cycle. The stages of each cycle within the study might be consulted in Figure 2.

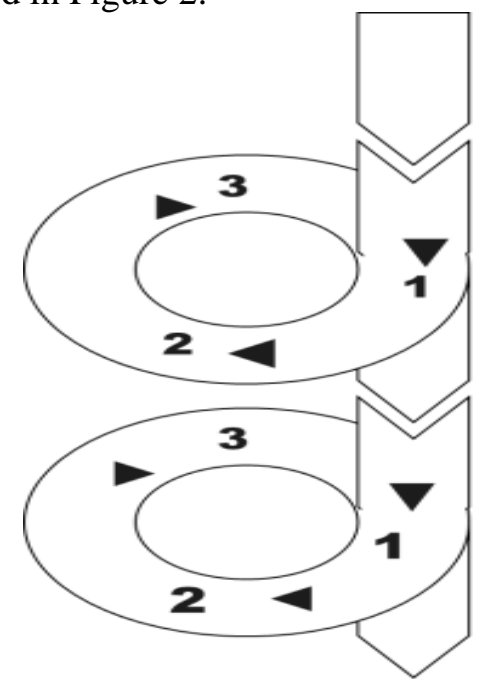

Figure 2. The Spiral Shape of Kemmis \& McTaggart Model

According to Figure 2, Planning Stage referred to the stage that tested the hypothesis by using the design that had been prepared. In this stage, the actions were designed in thorough, detailed, and wellprepared manner. The objective of was to avoid obstacles and to ensure that the conduct of test might be in accordance to the design that had been previously planned. Then, Action and Observation Stage referred to the implementation of the Action Stage that had been previously designed. Furthermore, the Observation stage referred to the stage in which the necessary data and information were gathered. Eventually, the Reflection Stage referred to the stage in which the processing results of the data that had been gathered from the observation were utilized as a matter of consideration in order to define the success rate of the Classroom Action Research. In this stage, appopriate actions that should be taken further might be defined as well.

With reference to the cycle, Kowangbinangun State Elementary School located in the District of Kalasan, Regency of Sleman, had been selected as the research site. During the conduct of the study, the subjects consisted of 28 Grade V students with 11 male students and 17 female students. 
Jurnal Prima Edukasia, 8 (1), 2020 - 23

Dedy Dwi Setyawan, Ali Mustadi

Within the conduct of the study, the variables consisted of the independent variable (X), namely the hidrorium learning media, and the dependent variable (Y), namely the students' critical thinking skills and the students' learning results. The data from both variables were collected by means of test instrument and non-test instrument. The test was administered by distributing the test items on the artificial ecosystem and the mutual independence among living organisms. In this regard, the test instrument had been analysed in terms of validity, reliability, item differential capacity, and difficulty level. The software that had been operated for the analysis was Anates Version 4.0.9.

On the other hand, the non-test instrument was assignment assessment instrument that aimed at measuring the students' critical thinking skills. The assessment instrument of the students' critical thinking skills was taken from the students' critical thinking skills assessment instrument Fuad et al. (2017); this instrument had been the modification of the Finken and Ennis (1993) Model, which was also the reference for the study. Last but not the least, the guidelines of the observation sheet for measuring the students' critical thinking skills might be consulted in Table 1.

Table 1. Guidelines for the Observation Sheet of the Students' Critical Thinking Skills

\begin{tabular}{|c|c|c|c|}
\hline $\begin{array}{l}\text { Definition of Critical } \\
\text { Thinking Skills }\end{array}$ & Aspects & Descriptors & $\begin{array}{c}\text { Item } \\
\text { Number }\end{array}$ \\
\hline \multirow{5}{*}{$\begin{array}{l}\text { Logical, reflective, and } \\
\text { productive thinking skills that } \\
\text { results in good decisions } \\
\text { based on evaluation results } \\
\text { toward a condition or a } \\
\text { situation }\end{array}$} & Focus & $\begin{array}{l}\text { Understanding the artificial ecosystem and } \\
\text { mutual dependency among the living } \\
\text { organisms }\end{array}$ & 1 \\
\hline & $\begin{array}{l}\text { Supporting } \\
\text { reasons and } \\
\text { reasoning }\end{array}$ & $\begin{array}{l}\text { Being able to draw conclusions on artifical } \\
\text { ecosystem and mutual dependency among } \\
\text { living organisms }\end{array}$ & 2 \\
\hline & Organization & $\begin{array}{l}\text { Being able to dusplay good thinking sequence } \\
\text { on all aspects of artificial ecosystem and } \\
\text { mutual dependency among living organisms }\end{array}$ & 3 \\
\hline & Conventions & $\begin{array}{l}\text { Being able to display good grammar and } \\
\text { coherence in the report of the observation } \\
\text { toward the artificial ecosystem and mutual } \\
\text { dependency among living organisms }\end{array}$ & 4 \\
\hline & Integration & $\begin{array}{l}\text { Being able to complete all elements of } \\
\text { observation report for artificial ecosystem and } \\
\text { mutual dependency among living organisms } \\
\text { namely: (1) appearance of the living } \\
\text { organisms; (2) data accuracy; and (3) data } \\
\text { proportion }\end{array}$ & 5 \\
\hline
\end{tabular}

The observation sheet (Table 1) was implemented in order to measure the level of the students' critical thinking skills. The activities that should be performed in measuring the students' critical thinking skills were namely: (1) compiling observation report; and (2) measuring the observation results by using the guidelines that had been designed.

The data analysis that had been adopted within the conduct of the study was the descriptive comparative analysis. According to the data analysis method, the quantitative data that had been attained or that had been described by means of explanation should be compared to the data that had been attained in each cycle. The objective of such comparison is to identify whether there had been improvement or not. The indicator of the success rate for the students' critical thinking skills and the students' learning results was that there was improvement that had been lower than or equal to $70 \%(\leq 70 \%)$. Eventually, the basic competence that had been selected for the conduct of the study was the Basic Competence 3.5: Analysis the Inter-Components Relationship and the Food Web within the Surrounding Environment.

\section{Results and Discussions}

In the first cycle, the Planning Stage was begun by preparing the materials, the learning sets, the observation worksheet, the observation sheet, and the hidrorium as learning media. The preparation was completely done by the teacher. Then, in the Action Stage, at the beginning the teacher provided stimulants in the form of narrative texts, reading materials, and video as well with regards to the materials that would be discussed. Then, the teacher provided opportunities for the students to observe, 
Jurnal Prima Edukasia, 8 (1), 2020 - 24

Dedy Dwi Setyawan, Ali Mustadi

raise questions, and gather information. Afterward, the teacher divided the students into seven groups and each group consisted of 4 people.

When the students had been completely divided, the teacher distributed the observation worksheet for each group and each group was assigned to perform observation. The observation sheet contained the direction and the order that should be carried out during the observation. Each group should have discussions in order to prepare the observation report. The general format of the observation report had been provided by the teachers in accordance to the guidelines of the students' critical thinking skills observation sheet. Then, the observation report that had been prepared later representd the students' conclusions toward the observation that they had performed. Based on the activities in the first cycle, it is found that the students' critical thinking skills and learning results have improved. The improvement might be consulted in Table 2 .

Table 2. The Frequency of the Students' Critical Thinking Skills in the First Cycle

\begin{tabular}{cccr}
\hline \multirow{2}{*}{ Category } & \multicolumn{3}{c}{ Critical Thinking Skills } \\
\cline { 2 - 4 } & Score Range & Number of Group & Percentage \\
\hline Very High & $76-100$ & 1 & $14 \%$ \\
High & $51-75$ & 4 & $57 \%$ \\
Low & $26-50$ & 2 & $29 \%$ \\
Very Low & $0-25$ & 0 & $0 \%$ \\
\hline
\end{tabular}

The data in Table 2 display the students' critical thinking skills from 7 groups each of which consists of 4 students. With reference to the data in Table 2, 14\% of the students belong to the "Very High" category, $57 \%$ of the students belong to the "High" category, and $29 \%$ of the students belong to the "Low" category.

In relation to the findings, Oktaviani (2018) suggest that the low level of the students' critical thinking skills level might impact the students' learning results. In other words, the students' learning results will improve when their level of critical thinking skills has been improved. Specific to the case of the study, the improvement of the students' learning results might be consulted in Figure 3.

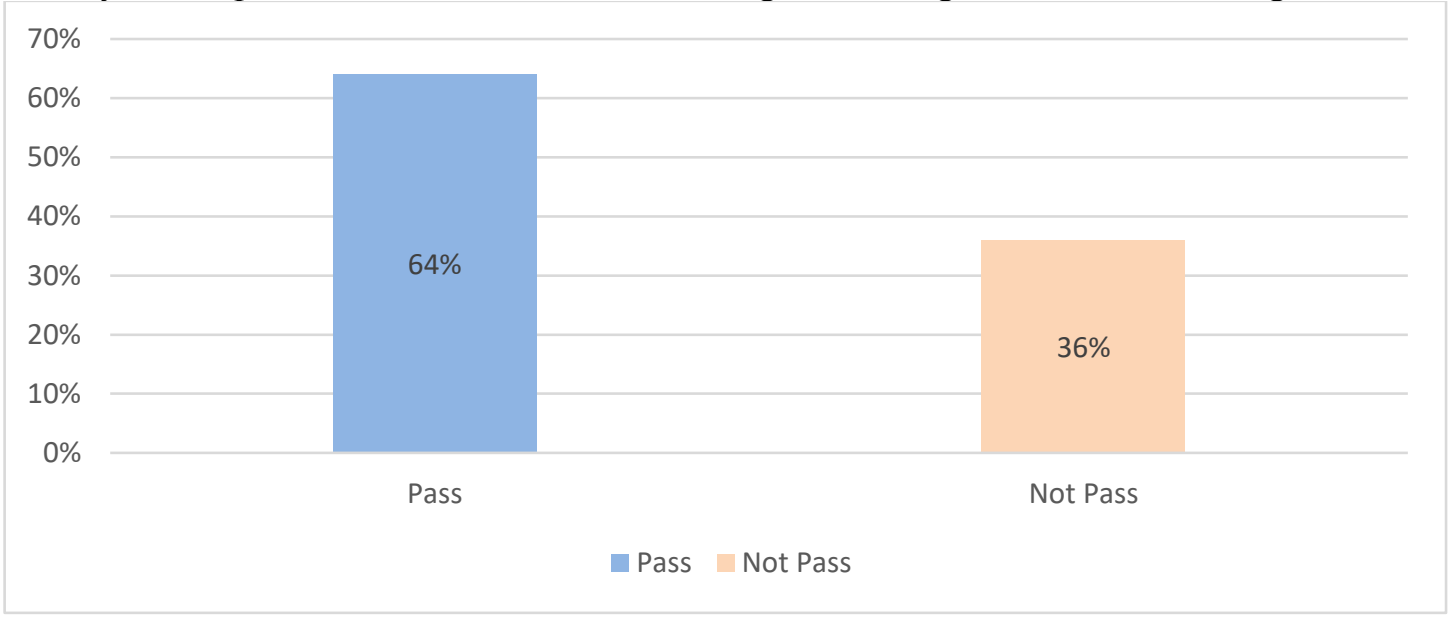

Figure 3. Graphic of the Students' Learning Results in First Cycle

Figure 3 displays that $64 \%$ of the students have met the passing grade while $36 \%$ of the students have not met the passing grade. This finding does confirm the improvement of the students' learning results in comparison to the pre-cycle situation.

In the first cycle, it is apparent that the students' critical thinking skills and learning results have not met the indicators of success that have been assigned. At the same time, within the first cycle it is also found that there have been some students who are busy with themselves and who are not actively involved in the learning process. The reason might be that there has only been one learning media for the seven groups, which comprise 28 students. Consequently, the observation that has been performed is less effective.

In order to improve the learning process in the second cycle, several reviews and revisions should be performed. One of such initiative is asking each group to create their own hidrorium media by looking at the teacher's hidrorium model. Through this activity, it is expected that each student might accurately 
Jurnal Prima Edukasia, 8 (1), 2020 - 25

Dedy Dwi Setyawan, Ali Mustadi

and openly observes the media in the group. In addition, another initiative is explaining again in details the procedures that will be performed in order that all students understand about what they have to do prior to the conduct of the learning process.

The revisions that have been pursued in the second cycle result in good impacts for the students. The students take more active role within the learning process and, at the same time, they observe and have discussions with their groups. During the administration of the test item, the students seem to be serious and sometimes they smile during the test item administration. The smile of the students might indicate that they understand the test items and they know the exact answers. Such indicator confirms the improvement within the students' critical thinking skills and learning results in the second cycle. In order to provide a better description, the results of the students' critical thinking skills in the second cycle might be consulted in Table 3 .

Table 3. Frequency of the Students' Critical Thinking Skills in the Second Cycle

\begin{tabular}{cccr}
\hline \multirow{2}{*}{ Category } & \multicolumn{3}{c}{ Critical Thinking Skills } \\
\cline { 2 - 4 } & Score Range & Number of Group & Percentage \\
\hline Very High & $76-100$ & 6 & $86 \%$ \\
High & $51-75$ & 1 & $14 \%$ \\
Low & $26-50$ & 0 & $0 \%$ \\
Very Low & $0-25$ & 0 & $0 \%$ \\
\hline
\end{tabular}

The data in Table 3 show that $86 \%$ of the students belong to the "Very High" category and $14 \%$ of the students belong to the "High" category. Departing from the data in Table 3, it seems that there has been significant improvement in comparison to the results in the first cycle. In line with the statement, the results of a study by (Hidayat, 2017, p. 7) show that the improvement of the students' learning results has been encouraged by the results of the improvement on the students' critical thinking skills. Then, the complete students' learning results in the second cycle might be consulted in Figure 4 .

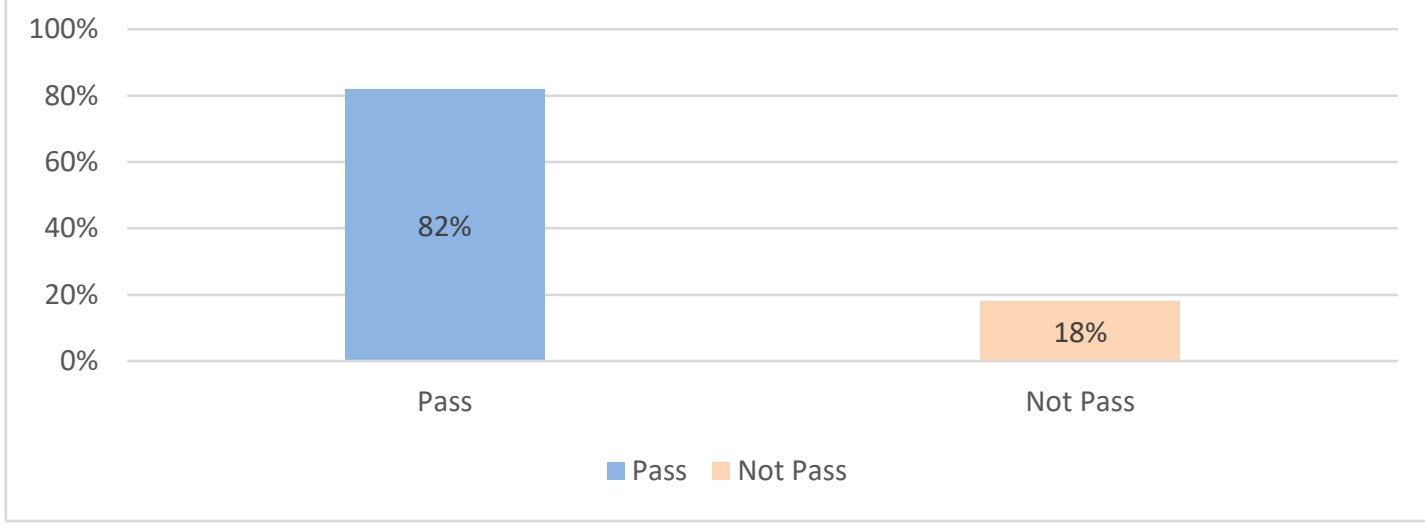

Figure 4. Graphic of the Students' Learning Results in the Second Cycle

The results in Figure 4 display that $82 \%$ of the students have met the passing grade and $18 \%$ of the students have not met the passing grade. Therefore, it might be concluded that there has been improvement in the second cycle after the revisions have been made.

Table 4. Comparison on the Students' Critical Thinking Skills Level and Learning Results in Grade V of Kowangbinangun State Elementary School

\begin{tabular}{ccrrr}
\hline \multirow{2}{*}{ Category } & \multicolumn{4}{c}{ Critical Thinking Skills } \\
\cline { 2 - 5 } & Score Range & Pre-Cycle & \multicolumn{1}{c}{ First Cycle } & Second Cycle \\
\hline Very High & $76-100$ & $4 \%$ & $14 \%$ & $86 \%$ \\
High & $51-75$ & $14 \%$ & $57 \%$ & $14 \%$ \\
Low & $26-50$ & $82 \%$ & $29 \%$ & $0 \%$ \\
Very Low & $0-25$ & $0 \%$ & $0 \%$ & $0 \%$ \\
\hline
\end{tabular}

Learning results might be defined as the achievements that a student has attained in order to deliver changes or character internalization (M. S. Astuti, 2015, p. 5). The success in the learning process might be attained when the existing conditions are already in accordance to the teacher's point of view. 
Jurnal Prima Edukasia, 8 (1), 2020 - 26

Dedy Dwi Setyawan, Ali Mustadi

In other words, it might be suggested that the second cycle has returned in success because the indicators of success that have been previously assigned have been met. Then, the comparison on the students' critical thinking skills level and learning results among the pre-cycle, the first cycle, and the second cycle might be consulted in Table 4.

With reference to the results in Table 4, in the pre-cycle $4 \%$ of the students belong to the "Very High" category, $14 \%$ of the students belong to the "High" category, and $82 \%$ of the students belong to the "Low" category. Then, in the first cycle little improvement has been made as having been displayed by the fact that $14 \%$ of the students belong to the "Very High" category, $57 \%$ of the students belong to the "High" category, and $29 \%$ of the students belong to the "Low" category. Eventually, in the second cycle higher improvement has been made as having been displayed by the fact that $86 \%$ of the students belong to the "Very High" category, 14\% of the students belong to the "High" category, and $0 \%$ of the students belong to the "Low" category. In addition to the comparison of the students' critical thinking skills, the comparison on the students' learning results might be consulted in Table 5.

Table 5. Comparison on the Students' Learning Results in Grade V of Kowangbinangun State Elementary School

\begin{tabular}{ccccr}
\hline \multirow{2}{*}{ Category } & \multicolumn{4}{c}{ Learning Results } \\
\cline { 2 - 5 } & Score Range & Pre-Cycle & First Cycle & Second Cycle \\
\hline Pass & $71-100$ & $33 \%$ & $64 \%$ & $82 \%$ \\
Not Pass & $0-70$ & $67 \%$ & $36 \%$ & $18 \%$ \\
\hline
\end{tabular}

The data in Table 5 show that in the pre-cycle $33 \%$ of the students have met the passing grade while $67 \%$ of the students have not. Then, in the first cycle $64 \%$ of the students have met the passing grade while $36 \%$ of the students have not. Eventually, after several reviews and revisions, in the second cycle $82 \%$ of the students have met the passing grade while $18 \%$ of the students have not.

The improvement on the students' critical thinking skills and learning results usually takes place in each cycle. The results of a study by Rahayu et al. (2019) show that the use of Discovery Learning Model might improve the students' critical thinking skills and learning results within each cycle. The stages in the Discovery Learning Model are quite similar to the stages in the use of hidrorium learning media. Concurrently, the results of a study by Rumini and Wardani (2016) show that the use of the Discovery Learning Model has been able to improve the Grade IV students' critical thinking skills and learning results.

Furthermore, a study by Khofiyah and Santoso (2019) show that the use of concrete objects has been able to improve the students' critical thinking skills despite the fact that the concrete objects that have been used are different. In addition, the results of a study by Kurniawati (2018) show that the use of interactive learning media has been able to improve the students' critical thinking skills in each cycle. Last but not the least, the results of a study by Suryansah and Suwarjo (2016) show that learning media development has been able to assist the improvement of the students' critical thinking skills. Similarly, the results of a study by Pebriani (2017) show that the use of video learning media has been able to improve the students' learning results and the improvement has been confirmed by the development of the cognitive domain through the use of concrete media stimulation.

\section{Conclusions}

The use of hidrorium learning media has been able to improve the students' critical thinking skills and learning results. In the first cycle, $14 \%$ of the students belong to the "Very High" category, $57 \%$ of the students belong to the "High" category, and $29 \%$ of the students belong to the "Low" category. Then, in the second cycle $86 \%$ of the students belong to the "Very High" category and $14 \%$ of the students belong to the "High" category. On the other hand, in the first cycle $64 \%$ of the students have met the passing grade while $36 \%$ of the students have not. In the second cycle, $82 \%$ of the students have met the passing grade while $18 \%$ of the students have not. Since the hidrorium learning media has been effective in improving the students' critical thinking skills and learning results, it might be suggested that the hidrorium learning media should be implemented in the materials of artificial ecosystem and mutual dependency among the living organisms. Then, it might also be suggested that the use of hidrorium learning media might improve the learning process quality toward the better description. Last but not 
Jurnal Prima Edukasia, 8 (1), 2020 - 27

Dedy Dwi Setyawan, Ali Mustadi

the least, the hidrorium learning media also provides direct learning experience so that the students might be more actively involved within the learning process.

\section{References}

Adnyana, G. P. (2012). Keterampilan berpikir kritis dan pemahaman konsep siswa pada model siklus belajar hipotetis deduktif. Jurnal Pendidikan Dan Pengajaran, 45(3). https://doi.org/10.23887/JPPUNDIKSHA.V45I3.1833

Astuti, M. S. (2015). Peningkatan keterampilan bertanya dan hasil belajar siswa kelas 2 SDN Slungkep 03 menggunakan model Discovery Learning. Scholaria: Jurnal Pendidikan Dan Kebudayaan, 5(1), 10-23. https://ejournal.uksw.edu/scholaria/article/view/3

Astuti, Y. W., \& Mustadi, A. (2014). Pengaruh penggunaan media film animasi terhadap keterampilan menulis karangan narasi siswa kelas V SD. Jurnal Prima Edukasia, 2(2), 250. https://doi.org/10.21831/jpe.v2i2.2723

Desmita, D. (2012). Psikologi perkembangan peserta didik. Rosdakarya.

Falahudin, I. (2014). Pemanfaatan media dalam pembelajaran. Jurnal Lingkar Widyaiswara, 1(4), 104117. https://juliwi.com/published/E0104/Paper0104_104-117.pdf

Finken, M., \& Ennis, R. H. (1993). Illinois critical thinking essay test. University of Illionis.

Fuad, N. M., Zubaidah, S., Mahanal, S., \& Suarsini, E. (2017). Improving junior high schools' critical thinking skills based on test three different models of learning. International Journal of Instruction, 10(01), 101-116. https://doi.org/10.12973/iji.2017.1017a

Hadi, P. (2016). Konsep prototype integrated verticulture aquaponic city farming di Kampung Batik Surakarta. Seminar Nasional \& Call For Paper DIES NATALIS XXXIII Universitas Islam Batik Surakarta, 131-141.

Hidayat, N. (2017). Peningkatkan kemampuan berpikir kritis dan hasil belajar siswa pada mata pelajaran matematika materi jaring-jaring bangun ruang melalui penerapan scientific approach kelas $\mathrm{V}$ Semester 2 di SDN 6 Dawuhan Situbondo tahun ajaran 2013/2014. JPDI (Jurnal Pendidikan Dasar Indonesia), 1(1), 7-10. https://doi.org/10.26737/jpdi.v1i1.114

Kemmis, S., McTaggart, R., \& Nixon, R. (2014). The action research planner: Doing critical participatory action research. Springer . https://doi.org/10.1007/978-981-4560-67-2

Khofiyah, H. N., \& Santoso, A. (2019). Pengaruh model discovery learning berbantuan media benda nyata terhadap kemampuan berpikir kritis dan pemahaman konsep IPA. Jurnal Pendidikan: Teori, Penelitian, Dan Pengembangan, 4(1), 61-67. https://doi.org/10.17977/jptpp.v4i1.11857

Kurniawati, I. D. (2018). Penerapan pembelajaran peer instruction berbantuan media pembelajaran interaktif untuk meningkatkan kemampuan berpikir kritis. Prosiding Seminar Nasional Teknologi Informasi Dan Komunikasi (SENATIK), $1(1), \quad 120-124$. http://prosiding.unipma.ac.id/index.php/SENATIK/article/view/873

Mulyasa, E. (2014). Guru dalam implementasi Kurikulum 2013. PT Remaja Rosdakarya.

Mustadi, A., Fauzani, R. A., \& Rochmah, K. (2018). Landasan pendidikan sekolah dasar. UNY Press.

Nurseto, T. (2012). Membuat media pembelajaran yang menarik. Jurnal Ekonomi Dan Pendidikan, 8(1). https://doi.org/10.21831/jep.v8i1.706

Oktaviani, W. (2018). Penerapan model pembelajaran discovery learning untuk meningkatkan kemampuan berpikir kritis dan hasil belajar matematika siswa kelas 5 SD. Jurnal Basicedu, 2(2), 5-10. https://doi.org/10.31004/basicedu.v2i2.137

Pebriani, C. (2017). Pengaruh penggunaan media video terhadap motivasi dan hasil belajar kognitif pembelajaran IPA kelas V. Jurnal Prima Edukasia, 5(1), 11-21. https://doi.org/10.21831/jpe.v5i1.8461

Putra, I., Pamukas, N. A., \& Rusliadi, R. (2013). Peningkatan kapasitas produksi akuakultur pada pemeliharaan ikan selais (Ompok sp) sistem aquaponik. Jurnal Perikanan Dan Kelautan, 18(1), 1-10. https://doi.org/10.31258/jpk.18.1.1-10

Rahayu, R. D. Y., Mawardi, M., \& Astuti, S. (2019). Peningkatan keterampilan berpikir kritis dan hasil 
Jurnal Prima Edukasia, 8 (1), 2020 - 28

Dedy Dwi Setyawan, Ali Mustadi

belajar siswa kelas 4 SD melalui model pembelajaran discovery learning. JPDI (Jurnal Pendidikan Dasar Indonesia), 4(1), 8-13. https://doi.org/10.26737/jpdi.v4i1.927

Rumini, R., \& Wardani, N. S. (2016). Upaya peningkatan hasil belajar tema berbagai pekerjaan melalui model discovery learning siswa kelas 4 SDN Kutoharjo 01 Pati Kabupaten Pati semester 1 tahun ajaran 2014-2015. Scholaria: Jurnal Pendidikan Dan Kebudayaan, 6(1), 19-40.

Sanjaya, W. (2008). Strategi pembelajaran berorientasi standar proses pendidikan. Prenada Media. https://doi.org/2008

Santoso, B., \& Arfianto, A. D. (2014). Sistem pengganti air berdasarkan kekeruhan dan pemberi pakan ikan pada akuarium air tawar secara otomatis berbasis mikrokontroler Atmega 16. Jurnal Ilmiah Teknologi Dan Informasi ASIA, https://www.jurnal.stmikasia.ac.id/index.php/jitika/article/view/173

Suryansah, T., \& Suwarjo, S. (2016). Pengembangan video pembelajaran untuk meningkatkan motivasi dan hasil belajar kognitif siswa kelas IV SD. Jurnal Prima Edukasia, 4(2), 209. https://doi.org/10.21831/jpe.v4i2.8393

Vikagustanti, D. A., Sudarmin, S., \& Pamelasari, S. D. (2014). Pengembangan media pembelajaran monopoli IPA tema organisasi kehidupan sebagai sumber belajar untuk siswa SMP. Unnes Science Education Journal, 3(2). https://doi.org/10.15294/usej.v3i2.3330 